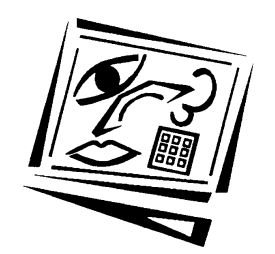

\title{
Drivers of learning management system use in a South African open and distance learning institution
}

Peet Venter, Mari Jansen van Rensburg and Annemarie Davis University of South Africa

\begin{abstract}
The study on which this article reports examined the determinants of usage of an online learning management system (LMS) by fourth level business students at a South African open and distance learning university using an extension of the widely used technology acceptance model (TAM) as a theoretical basis. A survey was conducted among students at their annual summer school, with 213 usable questionnaires being returned. The findings suggest that perceived usefulness and perceived ease of use as core aspects of the TAM and TAM2 models are confirmed, and study relevance (job relevance in the TAM2 model) and facilitating conditions as extensions are confirmed also. However, other elements of the TAM2 model and extensions were not confirmed by the research, while the relationships between these constructs, behavioural intention and LMS use were significant but not particularly strong. Thus, despite the ostensible robustness of the underlying structure and dimensionality of the TAM core constructs, its usefulness as a model to explain usage in this context and in a setting where acceptance and usage patterns have been established over prolonged periods of time is limited. The findings do, however, suggest certain initiatives to assist in increasing the perceived usefulness of the LMS.
\end{abstract}

\section{Introduction}

Growth in the adoption of online and mobile technologies as well as the application and evolution of these technologies to enable greater collaboration and interaction has been instrumental in the widespread use of e-learning platforms and applications by tertiary educational institutions. However, relatively little is known about the extent to which students at these institutions accept and use online learning management systems (LMS) in their learning. For open and distance learning (ODL) institutions worldwide, online and mobile learning systems have become especially important as a means of offering highly interactive and widely accessible learning solutions. It would thus seem important that developers and deliverers of learning solutions seek a deeper understanding of how students perceive and react to elements of technology-enabled learning and teaching. This is particularly true for ODL institutions in developing countries like South Africa, hampered by scarce resources, educational inequalities, lack of access to technology and low throughput rates.

Yet, despite the potential benefits of information technology in teaching and learning, one cannot ignore the numerous barriers to the integration of instructional technology into higher education. These barriers may include technological infrastructure, lecturer efforts, technological satisfaction, graduate competencies, high costs of technology, the absence of a business strategy, students' frustration with web-based education and under-utilised systems (Surry, Ensminger \& Haab, 2005, p. 328; Elloumi, 2004; and 
Hara, 2000). Indeed, low use of installed systems has been identified as a major factor underlying the 'productivity paradox' surrounding lacklustre returns from organisational investments in information technology (Sichel, 1997). Within the African context, the Association of African Universities (2011) indicated that the national ICT infrastructure in most African countries is still poor. There are few telephone lines and telephone users. Also, Internet user penetration in the region is still by far the lowest compared to any other world region, the available bandwidth is low and because of heavy reliance on private providers using satellites, the cost of high speed access to the Internet is prohibitively high. While these findings seem to support the claim that technology adoption in Africa is slower due to sub-Saharan Africa being technologically and economically less developed (Totolo, 2007, p. 2), Davis and Venter (2010) found that students at a South African university generally attach a high value to contact with lecturers and other students via electronic media such as online forums, text messages via mobile phones, and email. These findings suggest that a better understanding of the antecedents of and barriers to using learning management systems could lead to higher and more meaningful usage and a better learning experience.

While we acknowledge that barriers exist and influence the use of learning management systems within the context of higher education, this research project is an attempt to answer the call of Park (2009, p. 150) who confirmed the necessity to conduct research that deals more intensely with students' perception of, attitude towards and intention to use e-learning. This article furthermore responds to this need by examining the antecedents of learning technology use by advanced business students in the fourth level of business management studies at the University of South Africa (UNISA), a 'mega ODL' institution.

More specifically, we examine the perceptions and behaviour of students enrolled in Strategic Management, a capstone course that has been plagued by low throughput rates due to high levels of student dropout and failure. The LMS used by UNISA is a webbased system for academic collaboration and tuition related interaction. The system is called 'myUnisa' and uses the Sakai platform and offers tuition and administrative functions to develop and enhance academic interaction and improve communication between UNISA and its students. A fairly high percentage of students (96\%) on this program use the LMS, but most are passive users and only a few (13\%) are actively contributing to discussions and engaging with fellow students and lecturers. The number of active contributors is important, since previous exam results indicate that the pass rate for active contributors is significantly higher than for the noncontributors. For example in 2010, $78 \%$ of active contributors passed their final examination in Strategic Management compared to the $61 \%$ class pass rate. Getting students to engage more meaningfully online with other students and lecturers could contribute furthermore to increased social and academic integration (Kember, 1990), and possibly higher student retention and throughput.

The main purpose of our research was to identify the antecedents of e-learning use among advanced business students at UNISA, and for this purpose we used the Technology Acceptance Model (TAM) as a theoretical basis. The TAM was first developed by Davis (1989) to examine the acceptance of management information systems (MIS), and was later extended by Venkatesh and Davis (2000) (the revised model is referred to as TAM2) to reflect longitudinal research findings. TAM has been widely accepted and applied in a variety of settings due to its parsimony and explanatory power 
(Calantone, Yalcinkaya \& Griffith, 2005, p. 155) and has formed the basis by means of which one can examine the acceptance of e-learning by academics and educators (e.g. Thang, Murugaiah, Lee, Azman, Tan \& Lee, 2010; Tarcan, Varol \& Toker, 2010; Birch \& Burnett, 2009; Debuse, Lawley \& Shibl, 2008; Swan, 2009) and students (e.g. Park, 2009). However, research in Africa using TAM is limited. Oni and Ayo (2010) used the model to examine the acceptance of electronic banking in Nigeria, while Totolo (2007) investigated information technology acceptance by principals in Botswana secondary schools, but no examples of African applications of TAM in higher education could be found. This study will thus contribute towards a better understanding of the contextual issues related to TAM, since Calantone et al. (2005) highlighted the importance of contextual influences on technology acceptance in their adaptation of TAM for China.

In the following section we explore the TAM and its application in higher education. This is followed by a discussion of the research methodology, research findings and conclusion.

\section{The technology acceptance model (TAM) in higher education}

According to TAM, actual use of a technology system is influenced directly or indirectly by the user's behavioural intentions, attitude, perceived usefulness of the system and perceived ease of use. The behavioural intention is determined by attitude towards using technology. Attitude, in turn, is determined by two specific beliefs, namely perceived usefulness (the user's perception of the degree to which using a particular system will improve her/his performance), and the perceived ease of use (the user's perception of the extent to which using a particular system will be free of effort) (Davis, 1989; Davis, Bagozzi \& Warshaw, 1989).

TAM identified perceived usefulness (PU) as the single biggest contributor towards behavioural intention (BI) - the intention to use technology and ultimately towards actual usage behaviour (UB), while perceived ease of use (PEOU) exerted a strong influence on PU but a weaker direct influence on BI (Davis, 1989). BI acts as a mediator between other variables, which exert their influence on UB through this variable. This model also proposes that external factors affect intention and actual use through mediated effects of perceived usefulness and perceived ease of use (Park 2009, p. 151). Research findings suggest that TAM measures appear to be relatively free of measurement biases and that it is a robust model from both a theoretical and measurement perspective (Davis \& Venkatesh, 1996, p. 40).

The extension of the TAM (referred to as TAM2) was developed by Venkatesh and Davis (2000) to increase understanding of perceived usefulness. According to Venkatesh and Davis (2000, p. 187), PU is a fundamental driver of usage intentions and it is important to understand the determinants of the construct. As such, TAM2 incorporates additional theoretical constructs spanning social influence processes (subjective norm, voluntariness and image) and cognitive instrumental processes (job relevance, output quality, result demonstrability and perceived ease of use) to more comprehensively explain PU. This study also calls for further research on the determinants of PU in different contexts in order to enable the design of organisational interventions to increase user acceptance and usge of new systems. Figure 1 depicts the extended technology acceptance model (TAM2). 


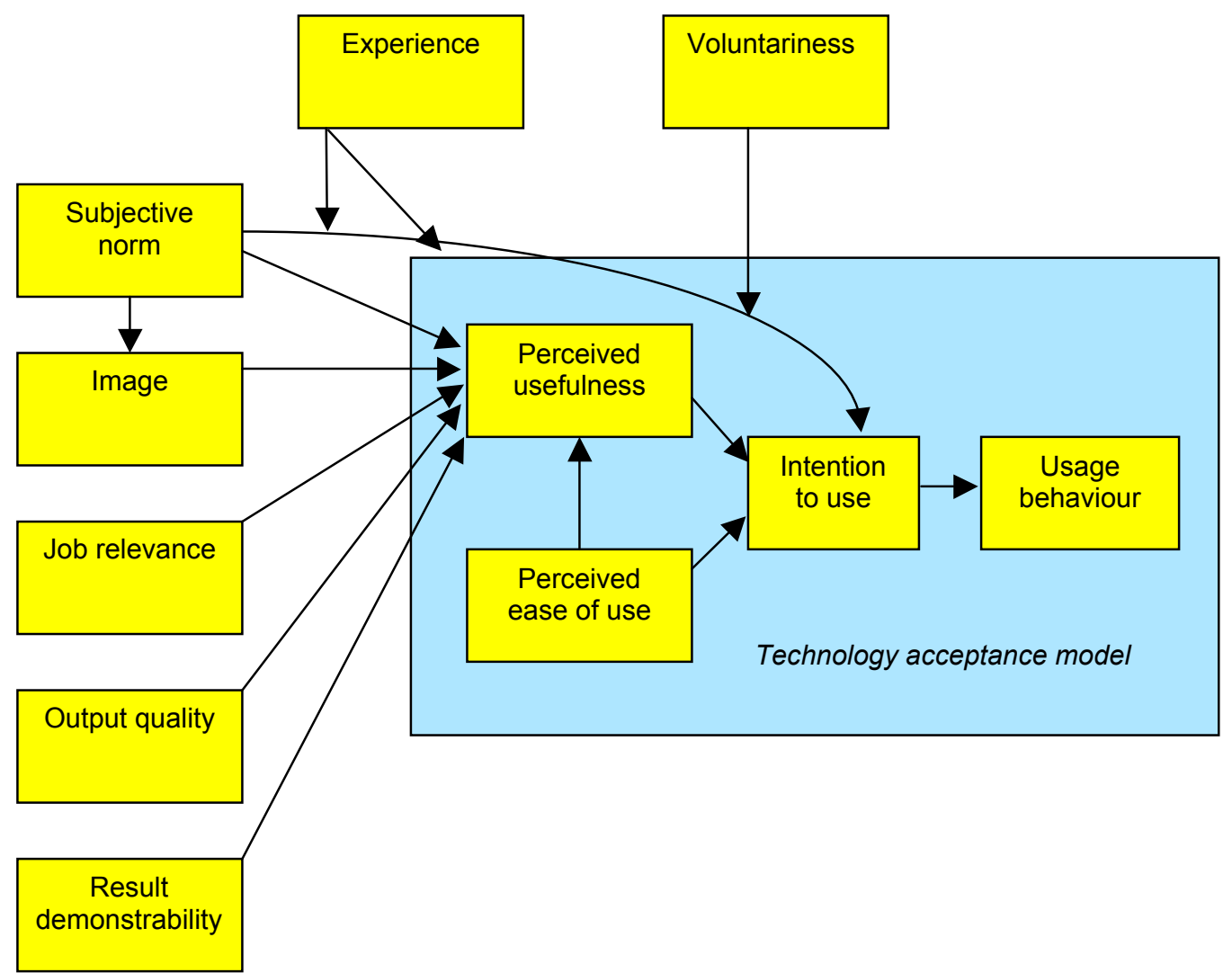

Figure 1: TAM2 (Venkatesh \& Davis 2000, p. 187)

Despite other available theoretical models that can be used for testing technology acceptance, such as Rogers' 'Diffusion of Innovations' (Rogers, 2003; Straub, 2009), the 'Concerns Based Adoption Model' (Hall, 1979), the alternative model for testing consumers' acceptance of technology (Chen \& Mort, 2007) and the 'Unified Theory of Acceptance and Use of Technology' (Venkatesh \& Zang, 2010), TAM remains the model most used and tested in various settings. This is no different for educational settings, where TAM has been used in various adaptations to test the acceptance of technology by lecturers and students alike. Table 1 provides a summary of the findings from selected studies in the higher education domain that have used TAM as a theoretical basis.

As summarised in Table 1, it is clear that results of previous research studies using TAM as a theoretical basis are varied, and often included additional factors such as attitude, facilitating conditions, self-efficacy, system design and experience. The factors also displayed various strengths of relationships between factors within different contexts. For example, Park's (2009) research among South Korean undergraduate students concluded that PU and PEOU had a much weaker direct influence on BI than Davis' (1989) findings suggest, although PU exerted a strong influence on attitude as a general measure of attitude towards technology. This was to some degree contradicted by the findings of Tarcan et al. (2010) who, in their study of the adoption of e-learning by Turkish academics, found PU and PEOU to be the strongest constructs explaining 
system use. Research findings generally supported the importance of PU and PEOU, validating their inclusion as key measures in the original TAM model.

Table 1: A summary of selected TAM applications in higher education settings

\begin{tabular}{|c|c|c|}
\hline Authors & Context & Findings \\
\hline $\begin{array}{l}\text { Shroff, } \\
\text { Deneen \& } \\
\text { Ng (2011) }\end{array}$ & $\begin{array}{l}\text { BEd students at } \\
\text { the Hong Kong } \\
\text { Institute of } \\
\text { Education }\end{array}$ & $\begin{array}{l}\text { Perceived ease of use (PEOU) had a significant effect on attitude } \\
\text { towards usage (ATU) and perceived usefulness (PU). The study } \\
\text { did not find a significant relationship between perceived } \\
\text { usefulness (PU), attitude towards usage (ATU) and behavioural } \\
\text { intention (BIU) to use the e-portfolio system. }\end{array}$ \\
\hline $\begin{array}{l}\text { Abbad } \\
(2010)\end{array}$ & $\begin{array}{l}\text { Students at the } \\
\text { Arab Open } \\
\text { University } \\
\text { (qualitative } \\
\text { study) }\end{array}$ & $\begin{array}{l}\text { While the results confirmed the robustness of perceived } \\
\text { usefulness (PU) and perceived ease of use (PEOU) as main } \\
\text { constructs of TAM, the study added five external factors, namely } \\
\text { subjective norm (SN), Internet experience (IE), system } \\
\text { interactivity (SI), self-efficacy (SE), and technical support (TS) } \\
\text { that could possibly explain students' intention to use LMS. }\end{array}$ \\
\hline $\begin{array}{l}\text { Ahmad, } \\
\text { Basha, } \\
\text { Marzuki, } \\
\text { Hisham \& } \\
\text { Sahari } \\
(2010)\end{array}$ & $\begin{array}{l}\text { Malaysian } \\
\text { academics }\end{array}$ & $\begin{array}{l}\text { Results generally supported the efficacy of the original TAM, and } \\
\text { the usefulness of its core constructs PU and BI in explaining } \\
\text { computer use. The researchers also extended the TAM model to } \\
\text { include self-efficacy (SE), and found that it was comparatively } \\
\text { more influential than BI in explaining computer usage. Older } \\
\text { academics were found to have more trouble accepting } \\
\text { technology than their younger counterparts. }\end{array}$ \\
\hline $\begin{array}{l}\text { Edmunds, } \\
\text { Thorpe \& } \\
\text { Conole } \\
(2010)\end{array}$ & $\begin{array}{l}\text { ODL students in } \\
\text { work-related } \\
\text { course at the } \\
\text { Open University } \\
\text { (UK) }\end{array}$ & $\begin{array}{l}\text { The researchers used the original TAM model for its simplicity } \\
\text { and robustness and found the choice validated by the outcome of } \\
\text { the study. PU and PEOU were found to be key aspects of } \\
\text { students' attitudes towards technology in all areas of their lives, } \\
\text { but ICT is perceived most positively in the work context. The } \\
\text { work context also appears as an important driver for technology } \\
\text { use in the other two areas of use. }\end{array}$ \\
\hline $\begin{array}{l}\text { Tarcan, } \\
\text { Varol \& } \\
\text { Toker } \\
(2010)\end{array}$ & $\begin{array}{l}\text { Turkish } \\
\text { academics at } \\
\text { seven state } \\
\text { universities }\end{array}$ & $\begin{array}{l}\text { The study used the original TAM model with subjective norm } \\
\text { (SN) and facilitating conditions (FC) as external variables. The } \\
\text { model reaffirmed the usefulness of the PU and PEOU in } \\
\text { explaining intention to use, while SN had a significant but not } \\
\text { particularly strong influence on PU, PEOU or BI. FC was found } \\
\text { to have only a relatively weak influence on PEOU, contrary to } \\
\text { previous research. }\end{array}$ \\
\hline Teo (2010) & $\begin{array}{l}\text { Pre-service } \\
\text { teachers at NIE, } \\
\text { Singapore }\end{array}$ & $\begin{array}{l}\text { The study employed path analysis to show that PU and PEOU } \\
\text { were the key determinants of their attitude towards computers. } \\
\text { The researcher added SN, FC and technological complexity (TC) } \\
\text { as external factors, and found that all three constructs were } \\
\text { significant in predicting computer use. }\end{array}$ \\
\hline $\begin{array}{l}\text { Waheed \& } \\
\text { Jam (2010) }\end{array}$ & $\begin{array}{l}\text { Academics at } \\
\text { the Allama Iqbal } \\
\text { Open } \\
\text { University, } \\
\text { Pakistan }\end{array}$ & $\begin{array}{l}\text { The study was based on the hypothesis that teacher's acceptance } \\
\text { and efficacy of new technology is important to the } \\
\text { implementation of web-based learning. Questionnaires were } \\
\text { used to check the influence of PEOU, PU, FC and computer } \\
\text { efficacy (SE) on the intention to implement e-learning } \\
\text { technology. They found strong empirical support for all four } \\
\text { constructs. }\end{array}$ \\
\hline Park (2009) & $\begin{array}{l}\text { South Korean } \\
\text { undergraduates, } \\
\text { residential } \\
\text { university }\end{array}$ & $\begin{array}{l}\text { The researcher used the structural equation modelling technique } \\
\text { to explain how university students adopt and use e-learning. The } \\
\text { research results proved TAM to be a good theoretical tool to } \\
\text { understand user's acceptance of e-learning. E-learning SE was } \\
\text { the most important construct, followed by SN in explicating the } \\
\text { causal process in the model. }\end{array}$ \\
\hline
\end{tabular}




\begin{tabular}{|l|l|l|}
\hline $\begin{array}{l}\text { Shen \& } \\
\text { Eder (2009) }\end{array}$ & $\begin{array}{l}\text { Undergrad and } \\
\text { continuing } \\
\text { studies students } \\
\text { in business }\end{array}$ & $\begin{array}{l}\text { A survey, based on TAM and extended factors, was administered } \\
\text { to business school students at a university in Northeastern USA. } \\
\text { Results suggest that PEOU affects user's intentions to adopt } \\
\text { Second Life through perceived usefulness. Computer SE and } \\
\text { computer playfulness were also significant antecedents to PEOU } \\
\text { of virtual worlds. }\end{array}$ \\
\hline $\begin{array}{l}\text { Martínez- } \\
\text { Torres et al. } \\
(2008)\end{array}$ & $\begin{array}{l}\text { Students } \\
\text { exposed to web- } \\
\text { tools in practical } \\
\text { and laboratory } \\
\text { teaching at a } \\
\text { university in } \\
\text { Spain }\end{array}$ & $\begin{array}{l}\text { lepends primarily on a user's behaviour. The researchers used } \\
\text { TAM to examine the acceptance of web-based e-learning tools } \\
\text { used in practical and laboratory teaching. The obtained results } \\
\text { strongly support the extended TAM in predicting student's } \\
\text { intention to use e-learning. PEOU did not posit a significant } \\
\text { influence in or intention towards e-learning tool usage. }\end{array}$ \\
\hline
\end{tabular}

On the other hand, perceived e-learning self-efficacy (SE) and subjective norm (SN) measures turned out to be influential measures in Park's (2009) study. SE (confidence in one's own abilities to use e-learning effectively) exerts a strong direct influence on both BI and PEOU. SN refers to the extent to which others who are important to the person believe that the behaviour in question should or should not be performed by the person (Tarcan et al., 2010, p. 795). Park found that SN exerts a relatively strong influence on PU. Ahmad et al. (2010) supported the findings with regard to SE, as their findings suggest that lecturers' computer self-efficacy has an important influence on both PU and UB. Tarcan et al. (2010) introduced facilitating conditions (FC) as an additional construct encompassing the organisational conditions such as training, education and technical support that create the environment for technology acceptance (or non-acceptance). FC was found to be positively linked to PEOU. The introduction of this variable was supported by findings from Abbad (2010) and Waheed and Jam (2010), while Abbad's (2010) research also suggested that Internet experience and system design may play a role in determining BI. Shroff, Deneen and Ng (2011. p. 600) examined students' behavioural intention to use an electronic portfolio system and, amongst others, their research demonstrated that individual characteristics and technological factors may have a significant influence on instructors to adopt eportfolios into their courses. Results suggest that TAM is a solid theoretical model where its validity can extend to an e-portfolio context.

The literature review generally suggests that TAM is the most widely used model to predict technology acceptance and, by implication, use. Possible reasons include the relative simplicity of the model (Edmunds et al., 2010, p. 3) combined with its relative theoretical robustness and psychometric accuracy in a number of different settings (Straub, Keil \& Brenner 1997, p. 1). The review also emphasises the robustness of the TAM model and its extensions, as results are generally supportive of TAM findings, despite adaptations to the model to reflect research objectives and contextual realities. In particular, findings generally support the notion that perceived usefulness and perceived ease of use are key variables across different contextual settings. This study adopted factors contained within TAM2, adapted for this specific context. In addition, facilitating conditions (FC) (Abbad, 2010; Waheed \& Jam, 2010) and attitude (AT) (Teo, 2010) were considered as potentially relevant factors. Given the focus of the study on advanced students, and the fact that most students in the selected university are already active on the system and have been for some time, 'experience' was not explicitly included in the scale, while 'system design' and perceived 'self-efficacy' were indirectly assessed by the user's experience of the system (for example perceived ease of use). 


\section{Research methods}

The study targeted advanced business students in their fourth level of study at UNISA enrolled in the Strategic Management course. Although students enrolled for this qualification are not required to have access to the Internet or computer facilities, access is highly recommended. All study material is distributed in hard copy as well as electronic format. There are normally in excess of 1,000 students (mostly from Southern Africa) enrolled for this course, and in order to ensure the inclusion of students who do not use the LMS frequently the questionnaire was distributed at the annual summer school conducted on 3 October 2010. Questionnaires were distributed to students at the start of the session with a request to complete the questionnaire during breaks. A short briefing informed students of the purpose of the study, their right to refuse participation and the confidentiality of their responses. Even though student participation was voluntary and students had to complete the questionnaire during their breaks a high response rate of $87 \%$ was achieved resulting in 213 completed and usable questionnaires.

A quantitative approach was used to collect the data, as TAM has been extensively tested and validated in different settings, and for this purpose a structured questionnaire could be developed with a relatively high measure of construct validity. The questionnaire design is outlined in Table 2.

Table 2: Questionnaire design

\begin{tabular}{|l|l|l|}
\hline $\begin{array}{l}\text { Questionnaire } \\
\text { section }\end{array}$ & \multicolumn{1}{|c|}{ Description } & \multicolumn{1}{c|}{ Rationale for inclusion } \\
\hline Q1 and Q2 & $\begin{array}{l}\text { Usage behaviour - how often the LMS is used } \\
\text { and for what (nominal data) }\end{array}$ & $\begin{array}{l}\text { Ultimately UB is the dependent } \\
\text { variable for the whole study. }\end{array}$ \\
\hline Q3-Q5 & $\begin{array}{l}\text { Measure access to and use of technology in } \\
\text { general (nominal data) }\end{array}$ & $\begin{array}{l}\text { Experience with technology } \\
\text { may be a predictor of UB }\end{array}$ \\
\hline $\begin{array}{l}\text { Q6 (28 scale } \\
\text { items) }\end{array}$ & $\begin{array}{l}\text { TAM scale (5-point Likert scale, 1 = completely } \\
\text { disagree and 5 = completely agree) }\end{array}$ & Allows TAM analysis \\
\hline Q7-Q10 & Demographics (nominal data) & $\begin{array}{l}\text { Allows for further analysis and } \\
\text { validation of data }\end{array}$ \\
\hline
\end{tabular}

The TAM scale for this survey was developed using the Venkatesh and Davis (2000, p. 201) TAM2 scale as a basis. However, this original scale reflected a focus on workrelated technology acceptance settings, and was subsequently adapted to reflect the ODL setting and the objective of measuring antecedents of LMS use. It was also decided to include some items dealing with organisational environment and support for LMS use, generally referred to as facilitating conditions (FC) (Abbad, 2010; Tarcan et al., 2010; Waheed \& Jam, 2010). Given the uncertainty of the role of attitude in TAM (Teo, 2010) two additional items were included to measure the construct. The intention to use the technology was also not emphasised in this study, as the students had been exposed to the LMS for some time and most had been using it to some extent. The objective of the research was rather to understand the actual level of usage as well as the antecedents of usage and perceived usefulness. Data analysis will be discussed in the following section.

\section{Research findings}

The profile of the respondents was roughly in line with the overall profile of UNISA students at this level and in this field of study. Most of the respondents were female 
(66\%), while the ethnic background tended to be Black African (60\%), White (21\%) and Indian (17\%). Most students were between 24 and 35 years $(60 \%)$ or between 36 and 49 years old $(25 \%)$, as could be expected of advanced level students in an ODL institution. However, due to the summer school being presented only on the Pretoria campus, respondents were biased towards the Gauteng province $(82 \%)$, compared to the $60 \%$ of students on this course residing in the province.

The first item in the questionnaire aimed to determine how often students used the LMS. Results indicate that $64 \%$ of students were frequent users of the LMS, using the application at least once a week. Occasional users of the system (using the system once a month) constituted $23 \%$, while $10 \%$ of users used the system less than once a month (infrequent users). By far the majority of the students were, therefore, at the least occasional users of the LMS, supporting our decision not to focus solely on behavioural intention but on actual usage behaviour.

The next question required respondents to indicate which activities they performed on the online LMS. The purpose of this question was to determine the level of usage. Only about $28 \%$ of respondents were active contributors, engaging with fellow students and lecturers and contributing to discussions on the LMS. Most students used the platform only for administrative purposes (i.e. to download material and submit assignments) or as passive observers, reading the postings from other students or lecturers but not contributing to discussions. Table 3 provides a cross-tabulation of 'frequency of use' and 'activities performed' on the LMS. Of the active contributors, $86 \%$ were also frequent users. These results were used to categorise respondents into one of three groups:

1. Administrative users use the LMS only for administrative purposes such as downloading material and submitting assignments.

2. Passive users use the LMS for administrative purposes, but also passively observe the activities of lecturers and fellow students.

3. Active contributors use the LMS for the preceding activities, but also contribute actively to discussions on the discussions forums.

Table 3: Student use of the LMS

\begin{tabular}{|l|c|c|c|c|}
\hline \multicolumn{1}{|c|}{ LMS activity } & $\begin{array}{c}\text { Infrequent } \\
\text { users } \%\end{array}$ & $\begin{array}{c}\text { Occasional } \\
\text { users } \%\end{array}$ & $\begin{array}{c}\text { Frequent } \\
\text { users } \%\end{array}$ & $\begin{array}{c}\text { Total students using } \\
\text { the activity } \%\end{array}$ \\
\hline Downloaded material & 5.7 & 20.8 & 60.9 & 87.4 \\
\hline Submitted assignments & 4.3 & 21.3 & 59.9 & 85.0 \\
\hline Read postings from lecturers & 6.2 & 21.7 & 62.8 & 90.7 \\
\hline Read postings from other students & 2.2 & 17.4 & 58.0 & 77.6 \\
\hline Contributed to forum discussions & 0 & 3.9 & 23.7 & 27.6 \\
\hline
\end{tabular}

With the growth in social media applications and their adoption, the use of these applications in teaching and learning is increasingly in the spotlight. Respondents were asked whether they use a particular social media application and also if they use it to connect with fellow students. As might be expected, Facebook was a popular application to use $(56 \%)$, with $20 \%$ of respondents also indicating that they use Facebook to connect to fellow students. Other social media applications were used, albeit to a lesser extent than Facebook. Mxit (a popular online mobile text chat application) was used by $16 \%$ of respondents, while LinkedIn and YouTube were also relatively popular (about 15\% each). However, none of the applications, other than Facebook, were used for connecting with other students. 
In order to understand the context in which students used technology, the respondents were asked to indicate where they access the Internet. Respondents were required to indicate all relevant options and results suggest that most students have multiple Internet access points (mean of 2.5 access points). Table 4 provides an overview of access points in order of use. It is of interest to note that students mostly access the Internet from computers at work and home, suggesting that mobile Internet access is still lagging behind the use of conventional computers.

Table 4: Internet access point

\begin{tabular}{|l|c|}
\hline Internet access point & $\%$ \\
\hline Computer at work & 69 \\
\hline Computer at home & 59 \\
\hline Laptop/notebook/netbook & 37 \\
\hline Cellular (mobile) phone & 31 \\
\hline Smartphone (e.g. Blackberry, HTC, iPhone) & 21 \\
\hline Internet cafe & 16 \\
\hline Friend or family member's computer & 6 \\
\hline UNISA campus / regional office & 6 \\
\hline
\end{tabular}

In addition to reporting on descriptive findings, the objectives of the study necessitated inferential statistics. Initial analysis attempted to replicate the methodology followed by Venkatesh and Davis (2000, p.194). However, the findings did not support the multitrait-multimethod matrix produced for TAM2. Next, the original TAM2 and additional constructs were replicated from scale items. However, only four constructs displayed high construct reliability (Cronbach's alpha >0.7) namely 'study relevance', 'facilitating conditions', 'perceived usefulness' and 'perceived ease of use'. These four constructs were retained for further analysis (see Table 5). It was of note that 'facilitating conditions' was rated significantly lower (mean of 3.36) by respondents compared to the other constructs, suggesting a possible focus area to target improvement initiatives.

Table 5: Constructs retained from previous studies

\begin{tabular}{|c|c|c|}
\hline Construct & Scale items & alpha \\
\hline \multirow{3}{*}{$\begin{array}{l}\text { Study relevance } \\
\text { (job relevance) } \\
\text { Mean }=4.31\end{array}$} & Using the LMS is relevant to my studies & \multirow[t]{3}{*}{0.802} \\
\hline & In my studies, using the LMS is important & \\
\hline & I find that using the LMS suits my learning style & \\
\hline \multirow{2}{*}{$\begin{array}{l}\text { Facilitating } \\
\text { conditions } \\
\text { Mean }=3.36\end{array}$} & When I need help to use the LMS, guidance is available to me & \multirow[t]{2}{*}{0.706} \\
\hline & $\begin{array}{l}\text { When I need help to use the LMS, a specific person is available to } \\
\text { provide assistance }\end{array}$ & \\
\hline \multirow{4}{*}{$\begin{array}{l}\text { Perceived } \\
\text { usefulness } \\
\text { Mean }=4.19\end{array}$} & Using the LMS can increase my academic performance & \multirow[t]{4}{*}{0.836} \\
\hline & $\begin{array}{l}\text { Using the LMS in my studies enhances my effectiveness as a } \\
\text { student }\end{array}$ & \\
\hline & Using the LMS can improve my academic performance. & \\
\hline & I find the LMS to be useful in my studies & \\
\hline \multirow{4}{*}{$\begin{array}{l}\text { Perceived ease } \\
\text { of use } \\
\text { Mean }=4.08\end{array}$} & I find the LMS easy to use & \multirow[t]{4}{*}{0.720} \\
\hline & My interaction with the LMS is clear and understandable & \\
\hline & Interacting with the LMS does not require a lot of mental effort & \\
\hline & I find it easy to get the LMS to do what I want it to do & \\
\hline
\end{tabular}

Exploratory factor analysis was used to determine whether the remaining scale items outside of these four factors, contained in the original TAM2 constructs, would display a different underlying structure. Once data screening was completed, the data matrix 
showed sufficient correlations in the appropriate range to justify the application of exploratory factor analysis. Further analysis showed that the Kaiser-Mayer-Olkin (KMO) test of sampling adequacy measured 0.793, while Bartlett's test of sphericity was highly significant at 0.001 (Hair, Black, Babin, Anderson \& Tatham, 2006, p. 126). These were all indications that the data could be meaningfully subjected to exploratory factor analysis. A principal component factor extraction method with Varimax rotation and Kaiser normalisation was used to obtain the best possible factor structure. From this analysis three factors were obtained with eigenvalues larger than 1 and explaining approximately $57 \%$ of the total variance. To determine the correlation between a scale item and a factor, a minimum factor loading of 0.5 was deemed acceptable, given the guidelines provided by Hair et al. (2006, p. 128). Cronbach's alpha was used as a measure of internal reliability for the identified factors. Only the first factor displayed internal reliability with a Cronbach's alpha that exceeded the suggested lower limit of 0.7 , and as a result of low alphas the remaining two factors were discarded. In order to present a comprehensive overview of the data, Table 6 provides a summary of the factors and items. The factors highlighted were not retained for further analysis. The original Venkatesh and Davis (2000) factor associated with each item is displayed in brackets next to each item.

Table 6: Factor analysis results

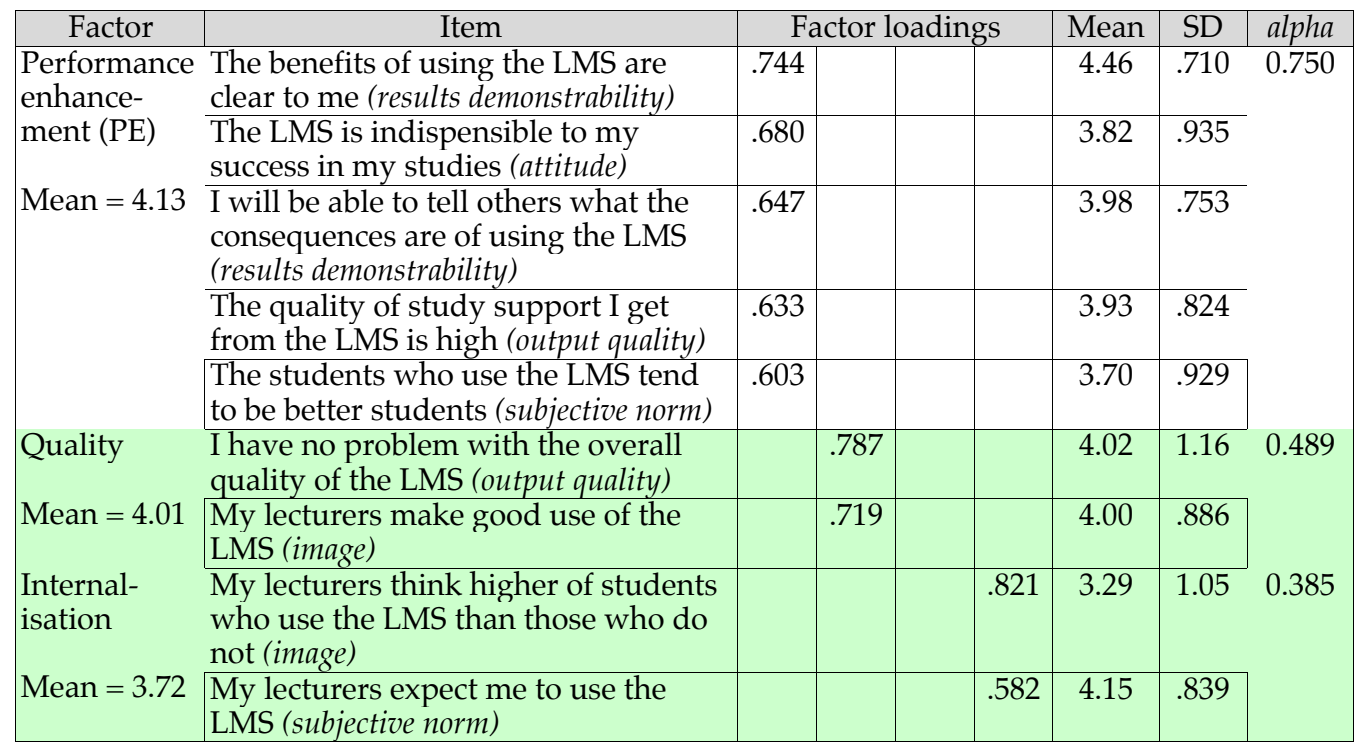

Factor 1 (see Table 6) was labelled 'performance enhancement' (PE), as it measures the extent to which students believe that the benefits obtained from using the LMS will enhance their studies. This factor contains a combination of original scale items from TAM2. Factor 2 was labelled 'quality' and factor 3 'internalisation'. Although both factors contain original TAM2 scale items, both were discarded for further analysis due to low internal reliability.

The next step was to determine whether the factors are correlated to usage behaviour and one another. As ordinal data was used, nonparametric correlation techniques had to be employed and therefore calculating the Spearman's rank correlation coefficient (Spearman's rho) was considered appropriate to determine associations and 
significance (Saunders, Lewis \& Thornhill, 2009). Spearman's rho coefficient (represented by the letter $r$ ) can take on any value between -1 and +1 . The value of +1 represents a perfect positive correlation while -1 represents a perfect negative correlation. Collis and Hussey (2009) suggest that correlations between 0.1 and 0.4 represent a weak positive correlation, while correlations between 0.4 and 0.7 represent a medium positive correlation and correlations higher than 0.7 are considered to be strong positive correlations. The results of this analysis are depicted in Figure 2. 'Study Relevance' and 'Performance Enhancement' both have a strong positive correlation with PU at a 0.001 level of significance. The remaining factors have a significant, but weak to medium positive correlation with behavioural intention and usage behaviour. This is depicted in Figure 2.

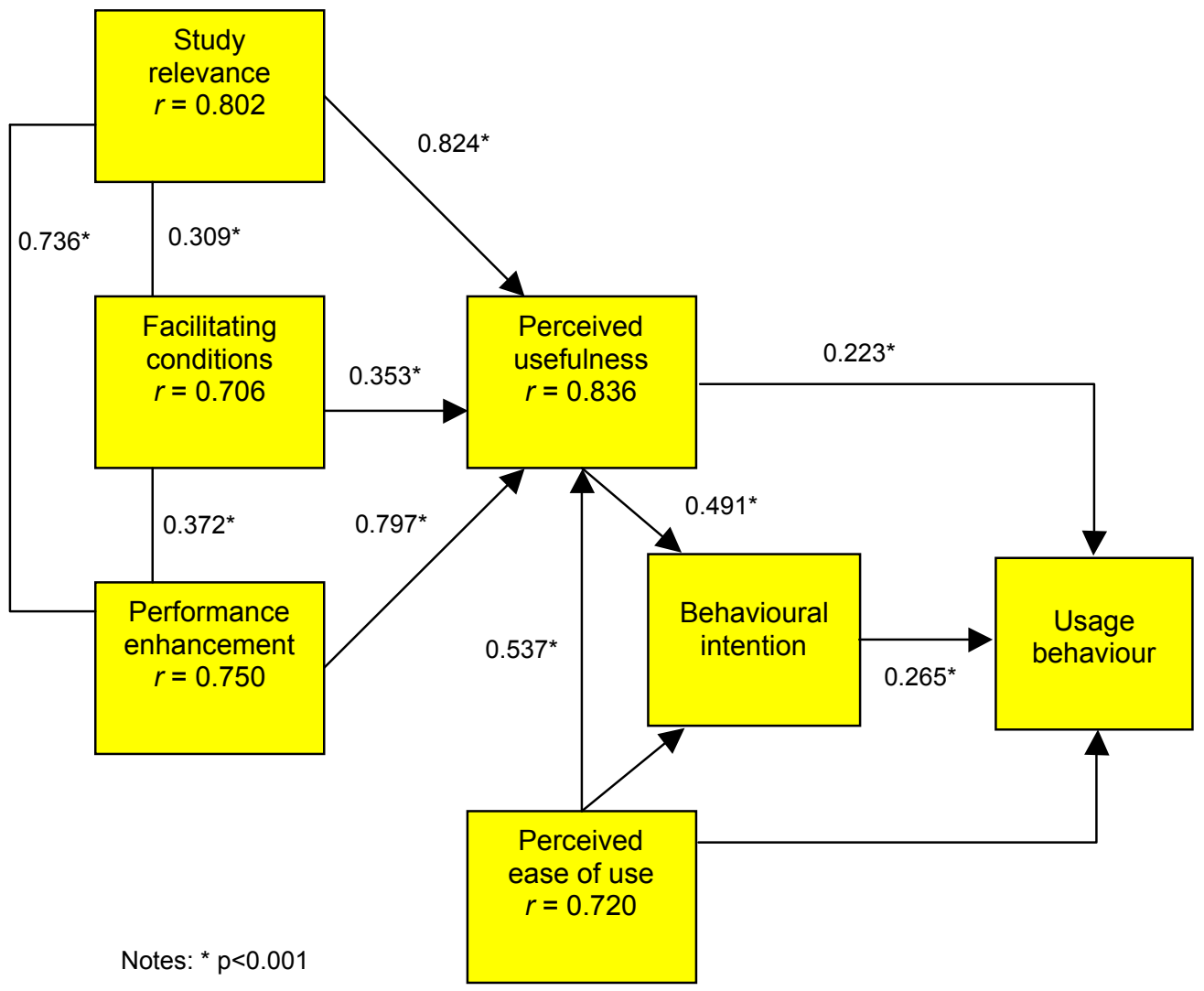

Figure 2: Graphic depiction of relationships between factors and usage behaviour

The findings depicted in Figure 2 confirm the usefulness of four of the TAM2 factors (perceived usefulness, perceived ease of use, facilitating conditions and study relevance), in line with the findings of several other studies (e.g. Shen \& Eder, 2009; Edmunds, Thorpe \& Conole, 2010; Teo, 2010). The study also seems to emphasise the general robustness of TAM, just as similar studies in other contexts have done (e.g. Park, 2009; Ahmad, Basha, Marzuki, Hisham \& Sahari, 2010; Tarcan, Varol \& Toker, 2010). Contextual differences are reflected in the performance enhancement factor. 
As a means of further exploring differences in usage behaviour, the three categories of users (administrative users, passive users and active contributors) were compared across all questions. A comparison of the factor means using Kendall's $W$ suggested that there are no significant differences between the three groups on their ratings of each of the factors. Using cross-tabulation and Chi-square testing, significant differences (at the 0.01 level of significance) were discovered in only two instances. Administrative users and passive users (60\% and 61\% respectively) both used Facebook significantly more than active contributors $(41 \%)$. On the other hand, active contributors $(46 \%)$ are much more likely to use mobile phones for accessing the Internet than either administrative users $(29 \%)$ or passive users $(27 \%)$. A possible explanation is that active users may be more results-focused and have less time for online social activities than their peers. Thus, even though they use mobile phones more for Internet access, they are less likely to use it for social purposes and more likely to use them for work or study. This finding seems to confirm the finding of Edmunds, Thorpe \& Conole (2010) that work context is an important driver of technology use.

The findings suggest that, while there is evidence that the identified factors contribute to usage behaviour, the statistical relationship between factors and usage behaviour is not particularly strong. This is further supported by the finding that there are few significant differences between the technology adoption and technology behaviour of administrative, passive and active users, suggesting that factors other than those explored in this survey may play a role in the extent to which students engage meaningfully with lecturers and fellow students online. These may include factors extraneous to students, such as the quality of instructional design, and the existence (or lack) of barriers to technology adoption.

\section{Conclusion}

The study set out to improve our understanding of the determinants of use and perceived usefulness to enable us to influence the discourses on institutional interventions that could increase meaningful usage of the LMS. The approach was student-centric, as it focused on the technology use and perceptions of students, rather than on extraneous factors such as the barriers to e-learning and technology acceptance. The aim of the research was to identify antecedents for usage behaviour with regard to the LMS implemented by UNISA. In order to investigate this, the extension of the technology acceptance model (TAM2) developed by Venkatesh \& Davis (2000) was used as a basis and extended by the inclusion of other items and variables identified in other studies using TAM and TAM2 in higher education settings (e.g. Park, 2009; Tarcan et al., 2010).

To some degree the results confirmed the robustness and explanatory power of TAM in higher education settings, as the underlying data structure mirrored the main TAM factors of perceived usefulness and perceived ease of use, and to a lesser extent the extensions of TAM2 in the form of study relevance (job relevance). There is also some support for other TAM extensions by other researchers in higher education, with 'Facilitating Conditions' being represented in this data. However, the underlying structure and dimensionality of the determinants of perceived usefulness did not reflect the original findings of TAM2. While the remaining items were subjected to exploratory factor analysis only one reliable new factor was added, namely performance enhancement. 
This study contributed to the growing body of research on technology acceptance and use in higher education by identifying constructs that explain perceived usefulness. Results suggest that study relevance, facilitating conditions and performance enhancement influence perceived usefulness.

The results did not provide as compelling an explanation of usage behaviour as the study set out to do. While the data showed that perceived usefulness (PU) and perceived ease of use (PEOU) have a significant relationship with behavioural intention and usage behaviour, the relationships were shown to be comparatively weak to moderate. This finding raises questions about the usefulness of TAM2 where usage patterns have already been established over prolonged periods of time.

Results also suggested that the online LMS is rated relatively highly on PU, PEOU, study relevance and performance enhancement, but less so on facilitating conditions, suggesting that the available support for students using the LMS could be improved and may lead to increased usage and a better overall student experience. Future research can focus on the determinants of usage behaviour by means of qualitative research in order to develop a deeper understanding of students' usage behaviour with regard to the LMS as well as developing a deeper understanding of lecturer acceptance and usage of the LMS.

The study was limited by its relatively narrow geographical and institutional focus. These limitations open up opportunities for future research. First, there is a need for similar research in other countries or regions in Africa. Second, more qualitative research can contribute to enhancing and deepening the understanding of the micropractices of faculty and students that drive the adoption and use of educational technology. Finally, the knowledge of technology adoption will be enhanced by studying it in relation to other course factors such as instructional design.

The results of the study left the authors with the realisation that, despite the similarities in findings between this study and other similar studies in higher education, usage behaviour of e-learning systems is a complex issue that is situated in a particular context and deserves more intense scrutiny. This necessitates developing a multifaceted perspective that includes research on students, lecturers, the system itself and the external environment using different methodologies. Ultimately, as lecturers, we owe it to our students to give them the best possible learning solutions.

\section{References}

Abbad, M. (2010). Learning from group interviews: Exploring dimensions of learning management system acceptance. International Journal of Instructional Technology and Distance Learning, 7(3), 25-39. http:/ / www.itdl.org/Journal/Mar_10/article03.htm

Ahmad, T. B. T., Basha, K. M., Marzuki, A. M., Hisham, N. A. \& Sahari, M. (2010). Faculty's acceptance of computer based technology: Cross-validation of an extended model. Australasian Journal of Educational Technology, 26(2), 268-279. http:/ / www.ascilite.org.au/ajet/ajet26/ahmad.html

Association of African Universities (2011). Strengthening the space of higher education in Africa. Concept note. http:/ / www.aau.org/?q=content/ call-abstract-corevip-under-themestrengthening-space-higher-education-africa 
Birch, D. \& Burnett, B. (2009). Bringing academics on board: Encouraging institution-wide diffusion of e-learning environments. Australasian Journal of Educational Technology, 25(1), 117134. http:/ / www.ascilite.org.au/ ajet/ ajet25/birch.html

Calantone, R., Yalcinkaya, G. \& Griffith, D. (2005). An empirical examination of competing technology acceptance models in the context of China. Paper presented at 2005 American Marketing Association Summer Marketing Educators' Conference, 29 July - 1 August, San Francisco.

Chen, C. H. \& Mort, G. S. (2007). Consumers' technology adoption behaviour: An alternative model. The Marketing Review, 7(4), 355-368. http: / dx.doi.org/10.1362/146934707X251119

Collis, J. \& Hussey, R. (2009). Business research: A practical guide for undergraduate and postgraduate students. (3rd ed.). Basingstoke: Palgrave Macmillan.

Davis, A. \& Venter, P. (2010). Online forums and mobile phones... can these really drive student performance? Paper presented at the 5th International Conference on ICT for Development, Education and Training, Lusaka, Zambia, 26-28 May.

Davis, F. D. (1989). Perceived usefulness, perceived ease of use, and user acceptance of information technology. MIS Quarterly, 13, 319-340. http: / / www.jstor.org/ stable/10.2307/ 249008

Davis, F. D., Bagozzi, R. P. \& Warshaw, P. R. (1989). User acceptance of computer technology: A comparison of two theoretical models. Management Science, 35, 982-1003. http: / / www.jstor.org/ stable/10.2307/2632151

Davis, F. R. \& Venkatesh, V. (1996). A critical assessment of potential measurement biases in the technology acceptance model: Three experiments. International Journal of Human-Computer Studies, 45(1), 19-45. http:/ / dx.doi.org/10.1006/ijhc.1996.0040

Debuse, J. C., Lawley, M. \& Shibl, R. 2008. Educators' perceptions of automated feedback systems. Australasian Journal of Educational Technology, 24(4), 374-386. http: / / www.ascilite.org.au/ajet/ajet24/debuse.html

Edmunds, R., Thorpe, M. \& Conole, G. (2010). Student attitudes towards and use of ICT in course study, work and social activity: A technology acceptance model approach. British Journal of Educational Technology, 43(1), 71-84. http:/ / dx.doi.org/10.1111/j.14678535.2010.01142.x

Elloumi, F. (2004). Value chain analysis: A strategic approach to online learning. In A. Anderson \& F. Elloumi (Eds.), Theory and practice of online learning (pp. 61-92). Athabasca, Canada: Athabasca University. http:/ / cde.athabascau.ca/online_book/

Hair, J. F., Black, W. W., Babin, B., Anderson, R. \& Tatham, R. L. (2006). Multivariate data analysis (6th ed.). Upper Saddle River, NJ: Pearson Prentice Hall.

Hall, G. E. (1979). The concerns based approach to facilitating change. Educational Horizons, 57(4), 202-208.

Hara, N. (2000). Student distress in a web-based distance education course. Information, Communication \& Society, 3(4), 557-579. http:/ / dx.doi.org/10.1080/13691180010002297

Kember, D. (1990). The use of a model to derive interventions which might reduce drop-out from distance education courses. Higher Education, 20(1), 11-24. http:/ / www.jstor.org/pss/3447427 
Martínez-Torres, M. R., Toral Marín, S. L., Barrero García, Gallardo Vázquez, F. S., Arias Oliva, M. \& Torres T. (2008). A technological acceptance of e-learning tools used in practical and laboratory teaching, according to the European higher education area. Behaviour $\mathcal{E}$ Information Technology, 27(6), 495-505. http:/ / dx.doi.org/10.1080/01449290600958965

Oni, A. A., \& Ayo, C. K. (2010). An empirical investigation of the level of users' acceptance of ebanking in Nigeria. Journal of Internet Banking \& Commerce, 15(1), 1-13. http: / / eprints.covenantuniversity.edu.ng/83/1/ Adesina.pdf

Park, S. Y. (2009). An analysis of the technology acceptance model in understanding university students' behavioural intention to use e-Learning. Educational Technology E Society, 12(3), 150162. http:/ / www.ifets.info/journals/12_3/14.pdf

Rogers, E. M. (2003). Diffusion of innovations. (5th ed.). Free Press: New York.

Saunders, M., Lewis, P. \& Thornhill, A. (2009). Research methods for business students (5th ed.). Essex: Pearson.

Shen, J. \& Eder, L.B. (2009). Intentions to use virtual worlds for education. Journal of Information Systems Education, 20(2), 225-233. http:/ / jise.org/Volume20/20-2/Pdf/V20N2P225-abs.pdf

Shroff, R. H., Deneen, C. D. \& Ng, E. M. W. (2011). Analysis of the technology acceptance model in examining students' behavioural intention to use an e-portfolio system. Australasian Journal of Educational Technology, 27(4), 600-618.

http:/ / www.ascilite.org.au/ajet/ajet27/shroff.html

Sichel, D. E. (1997). The computer revolution: An economic perspective. The Brookings Institution: Washington, DC.

Straub, E. T., Keil, M. \& Brenner, W. (1997). Testing the technology acceptance model across cultures: A three country study. Information $\mathcal{E}$ Management, 33(1), 1-11. http:/ / dx.doi.org/10.1016/S0378-7206(97)00026-8

Straub, E. T. (2009). Understanding technology adoption: Theory and future directions for informal learning. Review of Educational Research, 79(2), 625-649. http: / / dx.doi.org/10.3102/0034654308325896

Surry, D. W., Ensminger, D. C. \& Haab, M. (2005). A model for integrating instructional technology into higher education. British Journal of Educational Technology, 36(2), 327-329. http: / / dx.doi.org/10.1111/j.1467-8535.2005.00461.x

Swan, G. (2009). Examining barriers in faculty adoption of an e-portfolio system. Australasian Journal of Educational Technology, 25(5), 627-644. http: / / www.ascilite.org.au/ajet/ajet25/swan.html

Tarcan, E., Varol, E. S. \& Toker, B. (2010). A study on the acceptance of information technologies from the perspectives of the academicians in Turkey. Ege Academic Review, 10(3), 791-812. http: / / www.onlinedergi.com/MakaleDosyalari/51/PDF2010_3_3.pdf

Teo, T. (2010). A path analysis of pre-service teachers' attitudes to computer use: Applying and extending the technology acceptance model in an educational context. Interactive Learning Environments, 18(1), 65-79. http: / / dx.doi.org/10.1080/10494820802231327

Thang, S. M., Murugaiah, P., Lee, K. W., Azman, H., Tan, L. Y. \& Lee, Y. S. (2010). Grappling with technology: A case of supporting Malaysian Smart School teachers' professional development. Australasian Journal of Educational Technology, 26(3), 400-416. http:/ / www.ascilite.org.au/ajet/ajet26/thang.html 
Totolo, A. (2007). Information technology adoption by principals in Botswana secondary schools. Unpublished doctoral dissertation, Florida State University, Florida, USA. [verified 10 Feb 2012] http: / / etd.lib.fsu.edu / theses / available/ etd-07032007-

182055/ unrestricted/AngelinaTotoloDissertation.pdf

Venkatesh, V. \& Davis, F. D. (2000). A theoretical extension of the technology acceptance model: Four longitudinal field studies. Management Science, 46(2), 186-204.

http: / / www.jstor.org/ stable/10.2307/2634758

Venkatesh, V. \& Zang, X. (2010). Culture and technology adoption: Theory and empirical test of the unified theory of acceptance and use of technology (UTAUT) in the US vs China. Journal of Global Information Technology Management, 13(1), 5-27.

http: / / www.ivylp.com/catalog/item/7392377/7749767.htm

Waheed, M. \& Jam, F. A. (2010). Teacher's intention to accept online education: Extended TAM model. Interdisciplinary Journal of Contemporary Research in Business, 2(5), 330-344. [verified 8 Feb 2012, 6.3 MB] http: / /ijcrb.webs.com/sep\%2010.zip

Authors: Dr Peet Venter, Professor of Business Management, Department of Business Management, University of South Africa.

Email: ventep@unisa.ac.za Web: http:/ / www.unisa.ac.za/

Dr Mari Jansen van Rensburg, Associate Professor in Strategic Management, Department of Business Management, University of South Africa.

Email: jvrenm@unisa.ac.za Web: http: / / www.unisa.ac.za/

Ms Annemarie Davis, Senior lecturer in Strategic Management, Department of Business Management. University of South Africa.

Email: davisa@unisa.ac.za Web: http: / / www.unisa.ac.za/

Please cite as: Venter, P., Jansen van Rensburg, M. \& Davis, A. (2012). Drivers of learning management system use in a South African open and distance learning institution. Australasian Journal of Educational Technology, 28(2), 183-198.

http: / / www.ascilite.org.au/ajet/ajet28/venter.html 